\title{
Budaya Anak Punk di Yayasan Laskar Berani Hijrah (Studi Komunikasi Budaya Anak Punk di Depok)
}

\author{
Mikael Rainer Anggiprana, Suzy S. Azeharie \\ anggiprana1897@gmail.com,suzy@fikom.untar.ac.id \\ Fakultas Ilmu Komunikasi Universitas Tarumanagara
}

\begin{abstract}
Punk community are a distinguished group with its own unique culture. One of the most striking uniqueness of this community is their appearances which causes discomfort to the public and thus isolates them. Laskar Berani Hijrah Foundation is an institution which seeks to foster this punk community. The method used is based on Islamic teachings and the Holy Quran and its verses in it as a basis for guidance. This action is affecting the culture that the distinguished punk community held in the way they are communicating. The writer conduct a research that related to the cultural communication of the punk community in Laskar Berani Hijrah Foundation. Theories that is used in this research are ethnography theory and cultural theory. This research use qualitative approach that featured phenomenology as its method. Researcher choose four informants, whom are the chairman of the foundation, ustadz that also act as a mentor and two punks in the institution. This research conclude that the punk community in the Laskar Berani Hijrah Foundation performs cultural communication in verbal and nonverbal means, inside and also outside the routine activity that held by the foundation, influenced by two major factors that are their surroundings pressure as well as spiritual values implantation.
\end{abstract}

Keywords: punk, communication, culture communication.

\begin{abstract}
Abstrak
Anak punk merupakan kelompok yang memiliki budayanya sendiri. Salah satu budaya kelompok ini dapat dilihat dari cara mereka berpenampilan. Namun tampilan yang berbeda tersebut menimbulkan rasa kekhawatiran di masyarakat dan membuat kelompok anak punk menjadi semakin terasing. Yayasan Laskar Berani Hijrah membimbing anak punk untuk mengarahkan dan membimbing mereka menuju arah yang lebih baik dengan dasar agama Islam dan ayat-ayat Al Quran dalam berkomunikasi dalam binaan. Hal ini berdampak pada budaya dalam kelompok anak punk sendiri terutama dalam berkomunikasi. Penulis melakukan penelitian yang berkaitan dengan komunikasi budaya anak punk di Yayasan Laskar Berani Hijrah. Teori yang digunakan adalah teori etnografi komunikasi dan teori budaya. Penulis menggunakan pendekatan penelitian kualitatif dengan metode fenomenologi. Penulis memilih empat informan yang antara lain adalah ketua yayasan, ustad sekaligus pembimbing dan dua anak punk di yayasan tersebut. Kesimpulan dari penelitian ini adalah anak punk di Yayasan Laskar Berani Hijrah melakukan komunikasi budaya secara verbal dan nonverbal di dalam maupun di luar kegiatan rutin bersama yayasan yang dipengaruhi oleh dua faktor yaitu tekanan lingkungan serta penanaman keimanan dan spiritualitas kepada anak punk.
\end{abstract}

Kata Kunci: anak punk, komunikasi, komunikasi budaya

\section{Pendahuluan}

Indonesia memiliki tingkat kemiskinan yang cukup tinggi. Badan Pusat Statistik mencatat angka kemiskinan pada bulan September 2019 mencapai 9,22 
persen atau tercatat 24,79 orang. Meski ada penurunan angka dari September 2018, angka tersebut masih terhitung tinggi (Widyastuti, 2020).

Anak punk memiliki budaya yang berbeda dari kelompok anak-anak jalanan lainnya. Salah satu budayanya adalah cara mereka berpenampilan seperti tato, tindik, pakaian serta rambut yang dibentuk serta diwarnai. Pada umumnya mereka akan turun ke jalan untuk mencari nafkah dengan cara mengamen bersama. Alasan yang memicu rata-rata anak punk untuk turun ke jalan adalah kurangnya penyaluran minat dan bakat serta kurangnya kasih sayang dari orang tua (Rohman, 2009: 3).

Penampilan anak punk memicu kehawatiran di kalangan masyarakat. Kekhawatiran tersebut menciptakan stigma buruk masyarakat terhadap anak punk. Hal ini membuat anak punk semakin diasingkan sehingga menekan serta menghambat perkembangan pribadi dan sosial mereka karena sudah menjadi kebutuhan bagi manusia untuk dihormati dan disayang.

Yayasan Laskar Berani Hijrah merupakan lembaga yang memiliki pendekatan yang berbeda terhadap masalah tersebut. Yayasan ini merangkul anakanak jalanan seperti pengamen biola, manusia silver, anak-anak kecil dan anak-anak punk dengan tujuan untuk membimbing dan mengarahkan mereka menuju arah yang lebih baik.

Dalam melakukan bimbingan serta arahan, Yayasan Laskar Berani Hijrah menerapkan ajaran Islami. Anak-anak punk juga diberikan makan gratis dengan syarat menghafal ayat-ayat Al Quran di setiap pertemuan rutin yang diadakan setiap minggunya.

Penulis tertarik untuk meneliti karena adanya proses komunikasi yang terjadi berdasarkan budaya kelompok masing-masing yakni kelompok anak punk dan Yayasan Laskar Berani Hijrah. Ada kemungkinan bahwa budaya dalam yayasan mempengaruhi budaya kelompok anak-anak punk yang bergabung dalam Yayasan Laskar Berani Hijrah.

Pada penelitian ini, penulis ingin meneliti bentuk komunikasi budaya anak punk di Yayasan Laskar Berani Hijrah serta faktor-faktor yang mempengaruhinya. Penelitian ini menggunakan teori budaya yang dikemukakan oleh Koentjaraningrat dan teori etnografi komunikasi yang dikemukakan oleh Dell Hymes sebagai pengkategorian budaya. Pengkategorian tersebut adalah pelaku komunikasi yang patut dicontoh, pola komunikasi dari anggota kelompok, situasi atau segala waktu komunikasi yang tepat dalam komunitas dan kejadian atau percakapan dianggap komunikasi oleh anggota kelompok.

\section{Metode Penelitian}

Penulis menggunakan pendekatan penelitian kualitatif. Creswell mengatakan bahwa kualitatif adalah penelusuran atau pendekatan untuk memahami suatu titik gejala dengan mengekplorasi menggunakan pertanyaan umum yang diajukan kepada partisipan penelitian (Semiawan, 2010: 7). Penulis memilih pendekatan kualitatif karena paling sesuai untuk menggambarkan unit penelitian yaitu budaya anak punk di Yayasan Laskar Berani Hijrah.

Penelitian ini menggunakan metode fenomenologis sebagai penafsiran dan deskripsi sehubungan dengan rumusan masalah penelitian. Fenomenologi adalah upaya mendekati dan melihat suatu persoalan secara sadar serta mendeskripsikan suatu persoalan tersebut (Adian, 2016: 7). Rumusan masalah pada penelitian ini 
adalah bentuk komunikasi budaya serta faktor-faktor yang mempengaruhi komunikasi budaya anak punk di Yayasan Laskar Berani Hijrah.

Teknik pengumpulan data yang digunakan pada penelitian ini adalah wawancara, dokumentasi dan studi kepustakaan. Wawancara dilakukan dengan narasumber dengan melakukan tanya jawab dengan narasumber antara lain ketua Yayasan Laskar Berani Hijrah, ustad sekaligus pembimbing dan dua anak punk di Yayasan Laskar Berani Hijrah untuk mengetahui data berupa bentuk-bentuk komunikasi budaya kelompok anak punk di Yayasan Laskar Berani Hijrah. Peneliti menganalisis data-data yang telah diperoleh untuk ditarik kesimpulannya.

Teknik triangulasi digunakan oleh penulis sebagai pemeriksaan kredibilitas data dengan membandingkan data hasil wawancara dengan data kepustakaan. Sugiyono mengatakan triangulasi adalah pengumpulan data serta sumber data yang ada guna menguji kredibilitas data. Triangulasi juga dapat digunakan untuk mengumpulkan sekaligus menguji kredibilitas data (Sugiarto, 2015: 88).

\section{Hasil Temuan dan Diskusi}

Berdasarkan hasil wawancara dengan empat narasumber, diketahui bahwa Yayasan Laskar Berani Hijrah atau disingkat LEBAH merupakan lembaga yang bergerak dalam bidang kemanusiaan, recruitment dan pembinaan anak-anak jalanan. Pada tahun 2019, LEBAH dinyatakan resmi secara hukum menjadi bentuk Yayasan.

Yayasan Laksar Berani Hijrah melakukan kegiatan rutin bersama anak-anak punk di wilayah sekitar Depok setiap minggu. Kegiatan itu berupa pengajian, diskusi, ibadah, makan bersama dan membersihkan masjid bersama. Tidak hanya anak-anak punk, kegiatan ini dibuka untuk umum terutama bagi anak-anak jalanan lainnya seperti pengamen biola, manusia silver dan pengasong.

Ketua Yayasan LEBAH Wirawan Yogyasono mengatakan bahwa yang membedakan anak punk dengan masyarakat pada umumnya adalah lingkungan. Umumnya anak-anak ini menjadi anak jalanan karena empat faktor yaitu faktor ekonomi, faktor keluarga, faktor keturunan dan faktor lingkungan. Anak punk memodifikasi tubuhnya bukan hanya untuk diperhatikan orang sekitar tetapi juga untuk memperkuat jalin hubungan serta digunakan untuk menjamu tamu anak punk yang mungkin datang dari jauh. Selain itu Deki Kwarta selaku ustad sekaligus pembimbing menambahkan bahwa modifikasi tubuh tersebut juga sebagai pelampiasan hobi mereka dan menjadikan itu sebagai mata pencaharian mereka. Namun karena penampilan tersebut anak punk mendapat kecaman buruk dari masyarakat sekitar.

Wirawan menjelaskan bahwa dirinya percaya bahwa secara pribadi anak-anak punk ingin berkembang menjadi lebih baik, terutama dalam segi keahlian fisik. Dengan meningkatkan keahlian fisik, anak-anak punk akan semakin optimis akan masa depan mereka (wawancara online dengan Wirawan Yogyasono pada $18 \mathrm{Mei}$ 2020 pukul 21:00 WIB).

\subsection{Budaya Anak Punk Dalam Yayasan Laskar Berani Hijrah}

Koentjaraningrat mendeskripsikan bahwa kebudayaan merupakan tindakan, gagasan, karya dan sistem secara keseluruhan dalam kehidupan dan menjadikan itu milik manusia (Koentjaraningrat, 2015: 144). 
Anak-anak punk mempunyai budaya tersendiri dan budaya ini diteruskan dari satu orang ke orang lain. Budaya tersebut adalah cara mereka berpenampilan dengan tato, pakaian dan tindik, serta rambut yang dibentuk dan diwarnai. Selain itu, anak punk akan melakukan penggambaran tato pada tubuh anggota anak punk sebagai tanda penyambutan mereka ke dalam suatu kelompok punk dan memperkuat jalin hubungan. Deki Kwarta menambahkan hal ini menjadi benturan dan tantangan dalam binaan karena anak-anak punk akan dibina melalui ajaran agama Islam yang melarang adanya tato di tubuh (wawancara online dengan Deki Kwarta Achdani pada 20 Mei 2020 pukul 05:30 WIB).

Hal yang sama juga ditemukan di Desa Pegayaman Buleleng Bali. Adanya simbol-simbol budaya Bali seperti patung gerbang berbentuk gajah bertabrakan dengan ajaran agama Islam yang melarang penggambaran kemajuan dalam ilmu sosial (Azeharie, 2018).

Yayasan Laskar Berani Hijrah mengaplikasikan metode tersebut kepada anak-anak punk dalam binaan mereka. Namun yang dilakukan adalah sebaliknya, yaitu dengan menghapus tato sebagai bentuk penyambutan anak-anak punk yang siap berhijrah ke arah yang lebih baik (wawancara online dengan Wirawan Yogyasono pada 18 Mei 2020 pukul 21:00 WIB).

Deki Kwarta menambahkan bahwa penghapusan tato juga merupakan bentuk penyempurnaan jalan hijrah mereka. Keikhlasan anak-anak punk juga turut diuji dengan melakukan syarat menghapus tato yaitu dengan menghafal minimal dua puluh ayat dari Surah Ar Rahman. Dalam proses penghapusan tato, orang tua dari peserta penghapusan tato akan diundang untuk memberikan kesempatan kepada pada peserta untuk mengungkapkan rasa penyesalan dan kerinduan kepada orang tua secara langsung. Penghapusan tato ini dibuka untuk umum.

Anak-anak punk juga memiliki budaya berupa hukum yang tidak tertulis. Anak-anak punk tidak tinggal di satu tempat saja dan mereka aktif berkomunikasi dengan kelompok anak punk lainnya. Jika salah seorang mengecewakan temantemannya maka namanya akan tersebar dan anak punk tersebut dapat menjadi target bully dan akan kehilangan kepercayaan dari anak-anak punk lainnya.

Kegiatan lainnya adalah ibadah bersama, makan bersama dan menyetor ayatayat suci Al Quran. Peserta binaan akan diberikan kartu penyetoran ayat yang berguna sebagai data ayat-ayat yang telah berhasil dihafalkan di depan pembina secara langsung. Bagi mereka yang sudah melakukan penyetoran ayat maka akan diberikan makan gratis (wawancara online dengan Deki Kwarta Achdani pada 20 Mei pukul 05:30 WIB).

Alfa Shifa selaku anak punk dalam binaan mendukung pernyataan tersebut dan menambahkan bahwa dirinya bersama anak-anak punk lainnya juga aktif membersihkan masjid bersama, terutama di masa pandemi virus corona yang melanda Indonesia (wawancara online dengan Alfa Shifa Ramadhan pada 19 Mei 2020 pukul 19:35 WIB).

Wirawan juga melihat adanya perbedaan yang mencolok antara anak punk yang sudah menjalani binaan dengan anak punk yang belum atau baru menjalani binaan. Anak-anak punk yang sudah menjalani binaan tidak lagi melakukan kebiasaan buruk mereka seperti bermabuk-mabukan, begadang, bertengkar dan melakukan tindak kriminal (wawancara online dengan Wirawan Yogyasono pada 18 Mei 2020 pukul 21:00 WIB).

Dell Hymes dalam Stephen W. LittleJohn dan Karen A. Foss mengemukakan kategori yang membedakan budaya dalam etnografi komunikasi. Pertama adalah 
alasan seseorang untuk dicontoh. Kedua, cara berkomunikasi dalam kelompok. Ketiga, kondisi percakapan yang dianggap tepat. Keempat, adalah peristiwa yang dianggap komunikasi dalam kelompok (Littlejohn dan Foss, 2018: 461).

Dalam memilih acuan, Ahmad Sanusi merasa seseorang yang patut ia contoh adalah seseorang yang selalu menghargai, membimbing dan memandang semua orang sama. Menurut Ahmad orang itu adalah Ustad Deki. Ahmad juga merasa dihargai dan dibimbing secara sukarela yang menurutnya sudah jarang ditemui pada zaman yang ini (wawancara online dengan Ahmad Sanusi pada 19 Mei 2020 pukul 14:05 WIB).

Alfa Shifa Ramadhan turut menambahkan bahwa ia menjadikan Ustad Deki menjadi acuannya dalam berkomunikasi dan berperilaku karena Alfa menganggap Ustad Deki mampu merangkul orang lain dari yang baik hingga yang menurutnya tidak berakhlak dan menjadi orang yang lebih baik (wawancara online dengan Alfa Shifa Ramadhan pada 19 Mei 2020 pukul 19:35 WIB).

Cara berkomunikasi dalam kelompok dirasa tidak memiliki perbedaan dengan cara berkomuikasi di luar kelompok Yayasan Laskar Berani Hijrah. Ahmad Sanusi mengungkapkan bahwa caranya berkomunikasi di dalam dan di luar binaan tidak berbeda yaitu dengan saling menghargai dan mampu membedakan perilaku sesuai dengan tempatnya. Misalnya perilaku di jalan, berbeda dengan perilaku di rumah (wawancara online dengan Ahmad Sanusi pada 19 Mei 2020 pukul 14:05 WIB). Kemudian Alfa Shifa Ramadhan menambahkan bahwa dirinya berkomunikasi dengan cara memperlakukan lawan bicara seperti dirinya diperlakukan. Oleh karena itu, Alfa selalu berkomunikasi berdasarkan pada diri sendiri di luar maupun di dalam binaan (wawancara online dengan Alfa Shifa Ramadhan pada 19 Mei 2020 pukul 19:35 WIB).

Kondisi percakapan akan dianggap tepat jika sesuai dengan peristiwa yang terjadi saat itu. Deki Kwarta Achdani menyampaikan pengalaman di mana ia sering dihampiri oleh anak-anak punk yang dalam kondisi mabuk, meminta Deki untuk membimbing mereka. Deki selaku pembina selalu menyambut dan membimbing meski dalam kondisi tersebut (wawancara online dengan Deki Kwarta Achdani pada 20 Mei 2020 pukul 05:30 WIB).

Peristiwa yang dianggap komunikasi dalam kelompok atau kejadian-kejadian yang memiliki makna atau pesan dalam kelompok terjadi pada setiap kegiatan penghapusan tato. Peristiwa komunikasi tersebut adalah pengundangan orang tua dari anak-anak punk dalam binaan agar anak-anak punk dapat melepas kerinduan dan membanggakan orang tua mereka secara langsung dengan memperlihatkan tato mereka yang dihapus. Peristiwa ini juga menjadi penyemangat bagi anak-anak punk untuk berubah menjadi lebih baik (wawancara online dengan Deki Kwarta Achdani pada 20 Mei 2020 pukul 05:30 WIB).

Gambar 1. Anak punk dalam kegiatan penghapusan tato 


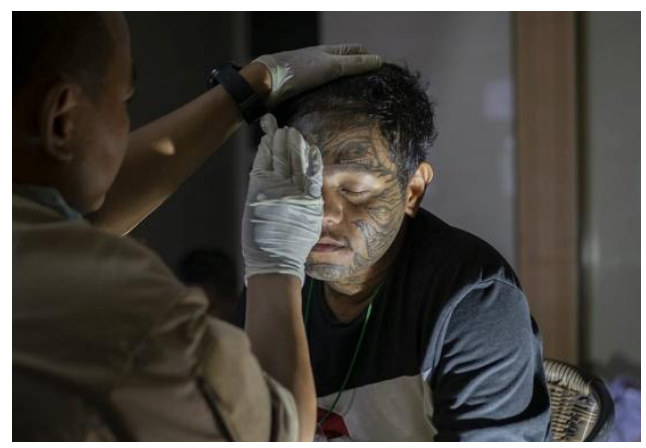

Sumber: Facebook@Konselor Wirawan Yosh diambil pada 22 Mei 2020

\subsection{Faktor-Faktor Yang Mempengaruhi Budaya Anak Punk di Yayasan Laskar Berani Hijrah}

Berdasarkan wawancara dengan Wirawan, anak-anak punk sendirilah menjadi faktor utama perubahan diri. Anak punk mengaku merasa lelah karena dipandang rendah oleh masyarakat sekitar. Rasa lelah itu menciptakan semangat untuk berubah menjadi sosok manusia yang lebih baik. Anak-anak punk memiliki rasa solidaritas yang tinggi maka mereka akan menularkan keinginan untuk berubah tersebut kepada teman-temannya.

Pernyataan ini didukung oleh Ahmad Sanusi selaku anak punk dalam binaan. Ahmad mengatakan bahwa dirinya lelah hidup di jalanan. Ahmad menganggap bahwa dirinya tidak akan berumur panjang bila ia terus mengikuti egonya karena dirinya telah menyaksikan beberapa temannya yang tewas akibat minuman beralkohol dan obat-obatan terlarang. Ahmad menambahkan, dukungan yang diterima dari Kapolres Depok berupa uang nominal sebesar Rp 800 ribu rupiah. Pihak Kapolres Depok mengaku bangga bahwa ada anak-anak punk yang mau menghafal surah Ar Rahman dan membaca ayat suci Al Quran

Faktor berikutnya adalah penanaman keimanan dan spiritualitas. Berdasarkan wawancara dengan Deki Kwarta Achdani, penanaman keimanan dan spiritualitas akan membuat niat mereka untuk berubah semakin matang. Wirawan turut menambahkan bahwa penting untuk memotivasi anak-anak punk untuk berubah menjadi lebih baik melalui ajaran agama Islam serta penanaman Surah Ar Rahman. Semakin kokoh keimanan mereka, semakin baik pula mereka dalam membedakan yang baik dan yang buruk.

\section{Simpulan}

Anak punk memiliki budayanya sendiri dan budaya tersebut diteruskan dari satu orang ke orang lain. Budaya anak punk yang pertama dapat dilihat dari cara mereka berpenampilan yaitu dengan pakaian yang sering kali compang-camping, rambut yang dibentuk dan diwarnai, tato dan tindik yang ada pada tubuh mereka.

Budaya yang kedua ialah adanya jamuan dari anak punk kepada anak punk yang merupakan pendatang dari jauh. Jamuan tersebut berupa penggambaran tato di tubuh anak punk pendatang tersebut. Selain untuk menjamu, penggambaran tato ini juga memiliki tujuan untuk memperkuat jalin hubungan.

Budaya yang ketiga adalah adanya hukum yang tidak tertulis bagi anak punk yang mengecewakan teman-temannya. Anak punk aktif berkomunikasi dengan kelompok punk lainnya. Jika salah seorang anak punk mengecewakan teman- 
temannya, namanya akan tersebar dan dirinya dapat menjadi korban bully serta dan kehilangan kepercayaan.

Kemudian komunikasi budaya anak punk di Yayasan Laskar Berani Hijrah yaitu anak punk aktif berkomunikasi dengan kelompok anak punk lainnya di wilayah Depok menggunakan media sosial Facebook dan Whatsapp dengan nama grup Depok City Burning. Anak-anak punk dalam binaan juga aktif melakukan komunikasi verbal dalam segala kegiatan seperti pengajian, penyetoran ayat dan diskusi yang rutin dilakukan setiap minggunya serta nonverbal yaitu dengan berlaku sopan kepada orang-orang sekitar dan saling berbagi makanan agar diri anak punk diterima oleh masyarakat sekitar. Anak-anak punk juga aktif dalam mengundang teman-teman mereka untuk ikut berubah menuju lebih baik bersama Yayasan Laskar Berani Hijrah

Adapun faktor-faktor yang mempengaruhi budaya anak punk di Yayasan Laskar Berani Hijrah seperti adanya tekanan dalam lingkungan sekitar yang mengecam anak-anak punk karena penampilannya serta adanya penanaman keimanan dan spiritualitas kepada anak-anak punk dalam binaan yang dilakukan secara rutin setiap minggunya.

\section{Ucapan Terimakasih}

Pada kesempatan kali ini, penulis mengucapkan terima kasih kepada Tuhan Yang Maha Esa karena atas rahmat-Nya peneliti dapat menyelesaikan penelitian ini. Terima kasih juga kepada para narasumber dari Yayasan Laskar Berani Hijrah, keluarga dan teman-teman terdekat penulis yang telah membantu dan mendukung penelitian ini.

\section{Daftar Pustaka}

Adian, Donny Gahral. (2016). Pengantar Fenomenologi. Depok: Koekoesan.

Azeharie, Suzy. (2018). Cultural Acculturation of the Villagers in Desa Pegayaman Buleleng Bali. Advance in Social Sience. Education and Humanities Research. (292).

Koentjaraningrat. (2015). Pengantar Ilmu Antropologi. Jakarta: PT Rineka Cipta.

Littlejohn, Stephen W dan Karen A. Foss. (2018). Teori Komunikasi Theories of Human Communication. Jakarta: Salemba Humanika

Semiawan, Conny R. (2010). Metode Penelitian Kualitatif Jenis, Karakteristik dan Keunggulannya. Jakarta: PT. Grasindo

Sugiarto, Eko. (2015). Menyusun Proposal Penelitian Kualitatif: Skripsi dan Tesis. Yogyakarta: Suaka Media.

Widyastuti, Ariyani Yakti. (2020). BPS: Angka Kemiskinan September 2019 Turun Jadi 9,22\%. https://bisnis.tempo.co/read/1295394/bps-angka-kemiskinanseptember-2019-turun-jadi-922-persen/full\&view=ok 